\title{
"120 em 60" \\ Práticas e atitudes de trabalhadores para com animais num matadouro português
}

\section{Rui Pedro Fonseca}

Instituto Universitário de Lisboa (ISCTE-IUL), Centro de Investigação e Estudos de Sociologia (CIES-IUL), Lisboa, Portugal

\begin{abstract}
Resumo Este estudo procura compreender as práticas e atitudes de trabalhadores que lidam com o abate $\mathrm{e}$ desmancha de animais num matadouro. Para o efeito, fez-se trabalho de observação, complementado com o uso de registos fotográficos, durante o "encaminhamento", "atordoamento", "pendura", "sangria" e "desmancha" dos animais na "linha de abate"; bem como o método de análise qualitativa, que requereu entrevistar oito indivíduos: duas mulheres e seis homens. Embora os trabalhadores reconheçam os animais como seres sensíveis, a operacionalização das suas tarefas na "linha de abate" está dependente de estratégias que requerem objetificação e distanciamento emocional. Foram também evidenciadas atitudes conflituosas relacionadas com determinadas espécies de animais. O contexto laboral (matadouro), o tempo despendido, as tarefas desempenhadas, a espécie dos animais, sobretudo o género e as trajetórias socioculturais dos trabalhadores destacaram-se como fatores predominantes de influência nas práticas e atitudes apuradas.
\end{abstract}

Palavras-chave: práticas, atitudes, indivíduos, suínos, matadouro.

"120 out of 60": practices and attitudes of workers towards animals in a Portuguese slaughterhouse

Abstract This study aims to understand the practices and attitudes of workers that deal with animals in a slaughterhouse. For this purpose, it was used photographic documentation during the "routing", "stunning", "hanging" and "bleeding" of animals in the slaughter line; also the method of qualitative analysis that required interviewing to eight individuals: two women and six men. Although workers recognize animals as sentient beings, the operationalization of their tasks in the slaughter line is dependent on strategies that require objectification and emotional distancing. Conflicting attitudes related to certain species of animals were also evidenced. Labor context (slaughterhouse), time spent, the performed tasks, animal species, particularly gender and socio-cultural trajectories of workers stood out as predominant factors that influenced their practices and attitudes.

$\underline{\text { Keywords: }}$ practices, attitudes, individuals, pigs, slaughterhouse.

"120 en 60": pratiques et attitudes des ouvriers envers les animaux dans un abattoir portugais

Résumé Cette étude cherche à comprendre les pratiques et les attitudes des ouvriers chargés de l'abattage et de la découpe d'animaux dans un abattoir. Le travail d'observation a été complété par des photographies prises pendant l'acheminement, l'étourdissement, l'accrochage, la saignée et la découpe des animaux sur la ligne d'abattage, ainsi que par l'analyse qualitative à partir d'entretiens avec huit personnes: deux femmes et six hommes. Bien que les ouvriers reconnaissent les animaux comme des êtres sensibles, l'opérationnalisation de leurs tâches sur la ligne d'abattage passe par des stratégies qui requièrent une chosification et une distance émotionnelle. Le cadre de travail (abattoir), le temps passé, les tâches accomplies, l'espèce des animaux, mais surtout le sexe et les parcours socioculturels des salariés, sont autant de facteurs qui influencent fortement les pratiques et les attitudes observées.

Mots-clés: pratiques, attitudes, individus, porcs, abattoir.

"120 en 60": prácticas y actitudes de trabajadores hacia los animales en un matadero portugués

Resumen Este estudio busca comprender las actitudes de los individuos (humanos) que se ocupan de la muerte y despiece de animales en un matadero. Para ello, se ha hecho un trabajo de observación y uso de registros fotográficos durante el "encaminamiento", "aturdimiento", "cuelgue", "sangría" y "despiece" de los animales en las "líneas de sacrificio"; así como un método de análisis cualitativo que requirió entrevistas 


\begin{abstract}
a ocho individuos: dos mujeres y seis hombres. Aunque los trabajadores reconozcan a los animales como seres sensibles, la operacionalización de sus tareas en la "línea de abate" depende de estrategias que requieren objetivación y distanciamiento emocional. También se evidenciaron actitudes conflictivas relacionadas con determinadas especies de animales. El contexto laboral (matadero), el tiempo empleado, las tareas desempeñadas, la especie de los animales, y sobre todo el género y las trayectorias socioculturales de los trabajadores, destacan como los principales factores de influencia en las prácticas y actitudes
\end{abstract} constatadas.

Palabras-clave: prácticas, actitudes, individuos, cerdos, matadero.

\title{
Introdução
}

Na atualidade, satisfazer o gosto pela "carne" não exige que grande parte dos consumidores tenham de realizar (ou de assistir) (a)o trabalho de criar ou abater os animais. Estando ausentes das vidas dos consumidores citadinos, o estatuto dos ditos "animais de produção" permanece continuadamente e consistentemente o mesmo - enquanto "referenciais ausentes" (Adams, 2003) (como "carne", "chouriços", "fiambre", "salpicão", "bife", etc.), o que resulta num inevitável distanciamento emocional, em que ninguém terá de sentir o fardo da responsabilidade pela morte dos que são consumidos. Mas o escoamento de produtos cárnicos para o mercado requer a existência de indivíduos que se encarreguem daquele que será o processo mais árduo e indesejado: o abate dos animais - que acarreta o acumular de tarefas como a sua descarga para as "abegoarias"; "encaminhamento"; "atordoamento"; "sangria" e "desmancha".

Estas práticas são usualmente realizadas em matadouros, "zonas de confinamento" (Pachirat, 2011), onde operam profissionais que têm autorização legal para abater animais de determinadas espécies. É um trabalho executado dentro de paredes e zonas de segurança, salvaguardando a devida distância entre os que lucram com a morte de animais e os possíveis intrusos (cf. Pachirat, 2011:4). O abate chega, aliás, a estar escondido de muitos trabalhadores que operam na própria "linha", como naquela observada (ver figura 2).

Abrindo uma ínfima brecha de um mundo praticamente impenetrável, esta pesquisa pretende contribuir para a compreensão das relações entre humanos e os animais, tornando visíveis algumas das práticas rotineiras que têm lugar num matadouro português. ${ }^{1}$ Os objetivos baseiam-se na compreensão:

Para além de excertos de entrevistas, este estudo contém imagens documentais das práticas de abate de animais. Foram dadas as respetivas permissões para publicação. Agradeço ao matadouro (cujo nome não é pertinente que tenha de ser tornado público) e a todos/as os/as inquiridos/as que entrevistei, observei, e que pretendo manter anónimos - daí todos os seus nomes estarem alterados. Agradeço, particularmente, ao Departamento de Qualidade do matadouro inquirido, pela sua disponibilidade em receber-me, e por toda a franqueza no esclarecimento de questões que foram surgindo durante e após a recolha de informação. Por fim, desejo dedicar este artigo aos 65 animais que foram abatidos à minha frente. 
(1) das práticas adotadas durante o "maneio", "abate" e "desmancha" de animais;

(2) da complexidade das atitudes dos trabalhadores que operam com estes animais;

(3) das trajetórias laborais, formas de organização social na "linha de abate", particularmente a pertinência da divisão sexual do trabalho.

\section{Metodologia}

Porque não se pretende expor o local visitado nem as pessoas que lá trabalham, o nome do matadouro e sua localidade não serão divulgados. Os trabalhadores entrevistados também são designados com outros nomes. Este trabalho de investigação implicou a adoção de três passos metodológicos:

(a) Aplicabilidade de entrevistas semiestruturadas a oito trabalhadores (seis homens + duas mulheres) que operam com animais. Foram aplicadas individualmente, questionando (oralmente) a amostra sobre o tempo de atividade, motivações, práticas adotadas, memórias, tarefas executadas, formas de organização social geradas em torno do abate e desmancha dos animais, eventuais dilemas éticos em abater determinados animais, se consideram as tarefas difíceis, etc.

(b) Através de trabalho presencial na "linha de abate", onde foi observada a performatividade dos inquiridos durante o "encaminhamento", "atordoamento", "sangria" e "desmancha" de 65 suínos. Fez-se uso do diário de campo e do registo fotográfico enquanto ferramentas complementares dos registos de observação. $^{2}$

(c) Conversas constantes, presenciais e por e-mail, com as duas trabalhadoras (técnicas de qualidade) do matadouro que, durante o processo da pesquisa, responderam a todas e quaisquer dúvidas que foram surgindo.

Após o término e primeira análise das entrevistas foi observada uma relevante correlação: que os percursos laborais dos trabalhadores resultam, em grande parte, de papéis tradicionais gerados em contextos familiares, de zonas rurais e periféricas, que desempenham uma influência central nas suas atitudes e comportamentos em relação aos animais explorados para fins alimentares. Ou seja, existem claros indícios de que a matança de animais é socializada, que está relacionada com a masculinização dos rapazes (Kheel, 1996), cujos esquemas de ação e pensamento podem ser, consciente ou inconscientemente, apreendidos e reforçados (Bourdieu, 1998). Sobretudo

2 De assinalar contingências relacionadas com a dificuldade de aplicação de entrevistas. Muitas empresas de produção / abate dos animais não responderam sequer à solicitação de colaboração com este estudo. "É um mundo muito fechado" - dizia, em entrevista, Serafim - proprietário de um outro matadouro de leitões que, entretanto, se recusou a colaborar mais com este estudo. Designadamente, este matadouro inquirido deixou de responder às minhas questões, bem como suspendeu um agendamento da minha presença durante o abate de animais bovinos. 
o abate dos animais de maior porte pode estar associado ao poder, virilidade, dominação (Parry, 2010), a um modelo de masculinidade mais "primitivo" (Rogers, 2008).

Também se recorreu aos números do Instituto Nacional de Estatística (INE, 2016), que apontam para uma presença assimétrica de homens e mulheres no dirigismo e na mão-de-obra dos contextos de produção animal portuguesa. Não existem, contudo, quaisquer números oficiais em relação aos matadouros. Mas esta tendência de masculinização do dirigismo e da força de trabalho do matadouro inquirido foi também constatada. Contudo, esta realidade motiva uma tentativa de explicação, um enquadramento teórico, interseccional, sobre as maneiras pelas quais múltiplas formas de opressão, dominação e subordinação (Adams, 2003) podem atuar em relação ao género, espécie, classe, etc.

De realçar a importância de trabalhos etnográficos já realizados, com observação participante, como o de Rhoda Wilkie (2010), sobre as experiências e atitudes das pessoas trabalhadoras do nordeste da Escócia, que lidam diretamente com os animais explorados para fins alimentares. Também o trabalho de Timothy Pachirat (2011) num matadouro dos Estados Unidos, que dá a conhecer as interações da força de trabalho e as formas que os animais são manuseados.

\section{Dados introdutórios sobre o matadouro observado}

Em Portugal, a produção / abate de animais para fins alimentares dispõe de uma complexa divisão sexual do trabalho, com mais presença de homens no dirigismo e na mão-de-obra menos qualificada. A classe dirigente, a que detém o poder económico e o monopólio de todas as atividades ligadas à produção animal portuguesa, é claramente masculinizada $(78 \%){ }^{3}$ Mas, ao contrário do que sucede na produção doméstica (espaço privado, de reprodução), em que o maneio dos animais está mais a cargo das mulheres, a mão-de-obra da média e da grande produção é predominantemente masculina $-75 \%$ (ver quadro 1 ).

Não foram encontradas quaisquer estatísticas sobre a representatividade de trabalhadores (por sexo) nos matadouros portugueses. Mas, conforme a figura 1, a presença de homens no matadouro observado é claramente dominante: a Direção e o Departamento Comercial apresentam lugares exclusivamente ocupados por homens; o Departamento Financeiro dispõe de dois homens e uma mulher; no Departamento de Qualidade operam duas funcionárias ${ }^{4}$ - responsáveis pela monitorização do "bem-estar animal"; na "linha de abate", que inclui "desmancha", trabalham 20 indivíduos (19 homens e uma mulher) em que, invariavelmente, os homens se ocupam dos equipamentos mais pesados e se encarregam exclusivamente do "encaminhamento", "atordoamento", "pendura" e

3 Instituto Nacional de Estatística (INE, 2016, “Inquérito à estrutura das explorações agrícolasdirigentes da exploração agrícola por orientação técnico-económica e sexo").

4 Foram as duas funcionárias do Departamento de Qualidade que sempre atuaram como representantes do matadouro, que agendaram as entrevistas com os trabalhadores e que me acompanharam durante o trabalho de observação na "linha de abate". 
Quadro 1 Mão-de-obra (por sexo) da exploração animal portuguesa (2016) ${ }^{(1)}$

\begin{tabular}{lrr}
\hline Tipos de exploração & Homens & Mulheres \\
\hline Bovinos - leite & 91.758 & 28.656 \\
Bovinos - criação e carne & 196.390 & 54.644 \\
Bovinos - leite. criação e carne combinada & 5.833 & 1.578 \\
Ovinos & 96.660 & 37.359 \\
Ovinos e bovinos combinados & 16.875 & 3.830 \\
Caprinos & 21.945 & 9.012 \\
Diversos herbívoros & 28.127 & 9.381 \\
Suínos para criação & 12.037 & 1.950 \\
Suínos de engorda & 1.680 & 0.226 \\
Criação e engorda de suínos & 8.239 & 2.936 \\
Galinhas poedeiras & 4.129 & 6.955 \\
Aves de carne & 15.189 & 11.632 \\
Galinhas poedeiras e aves de carne & 1.733 & 0.474 \\
Combinações de granívoros & 3.731 & 4.944 \\
Total & 516.363 & 173.577 \\
\end{tabular}

${ }^{(1)}$ Dados retirados do INE, que incluem as somas mão-de-obra familiar e mão-de-obra não familiar, bem como trabalhadores permanentes e eventuais (cf. INE, 2016, "Inquérito à estrutura das explorações agrícolas dirigentes da exploração agrícola por orientação técnico-económica e sexo").

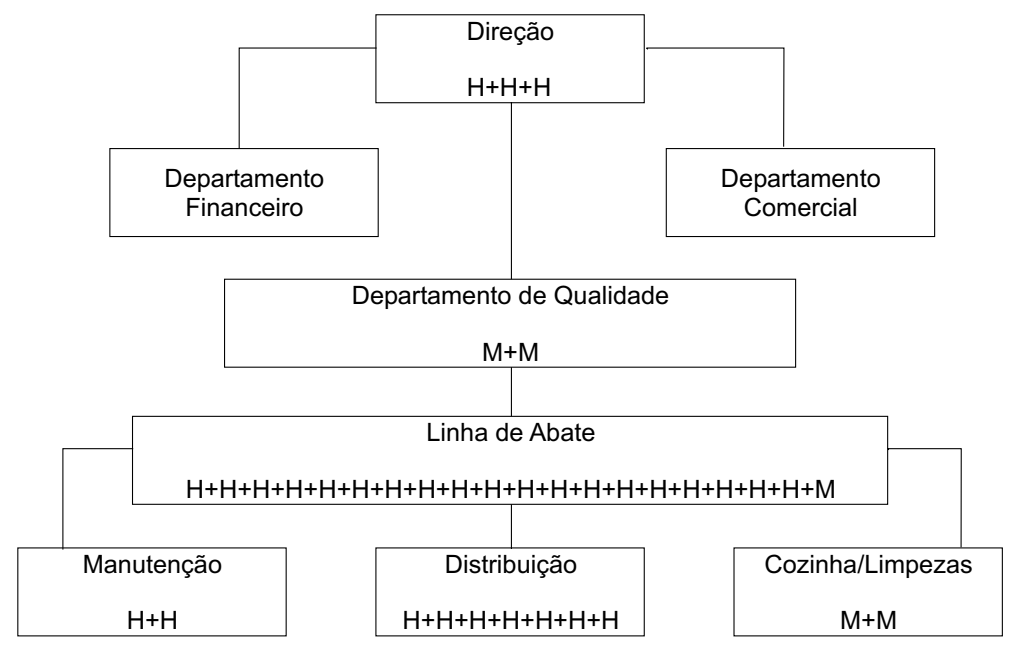

Figura 1 Estrutura organizacional (por género) do matadouro inquirido

"sangria" dos animais. A manutenção dos equipamentos e a distribuição / transporte das "peças" a superfícies comerciais locais é mão-de-obra exclusivamente masculina.

Já as mulheres ocupam-se das tarefas que acarretam menores riscos, na triparia, cozinha e limpezas do matadouro. 
Quadro 2 Estatísticas do abate de animais / espécie no matadouro observado (2018)

\begin{tabular}{lr}
\hline Suínos & 19.338 \\
Leitões & 685 \\
Bovinos (vitelos) & 2.184 \\
Ovinos ( jovens+adultos) & 16.569 \\
Caprinos (jovens+adultos) & 3.216 \\
TOTAL & 41.992 \\
\hline
\end{tabular}

Fonte: Estatísticas fornecidas pelo próprio matadouro.

Este matadouro empregava (em 2018) cerca de 39 pessoas, alcançando um volume bruto de negócios de 6.083.998 euros. ${ }^{5}$ De acordo com o Departamento de Qualidade do matadouro inquirido foram abatidos, no mesmo ano, cerca de 41.992 animais (ver quadro 2), montante que certamente contribuirá para os cerca de 52 milhões de animais (das espécies bovina, suína, ovina, caprina, aves, coelhos e galinhas poedeiras) (UN-FAO, 2009/2010) que em média serão mortos, em território português, para serem convertidos em produtos de origem animal.

\section{"120 em 60 minutos": etapas e práticas observadas na linha de abate}

À semelhança da produção agropecuária em regime intensivo, o abate de animais em matadouros é também orientado pela "eficiência produtiva" e "eficácia económica". ${ }^{6}$ Vigora, portanto, com uma doutrina essencialmente comercial, almejando a obtenção de uma elevada saída de produtos (de origem animal) pelo período de tempo mais curto possível - o que envolve uma elevada aceleração do abate e do processamento de animais. De acordo com o Departamento de Qualidade do matadouro, a "linha de abate" de suínos observada alberga, normalmente, 20 trabalhadores (19 homens + uma mulher), e tem a capacidade de abater 100-120 porcos em 60 minutos. É um sistema que, complementando maquinaria e mão-de-obra (humana), torna a morte de animais altamente eficiente (ver figura 2). ${ }^{7}$

Numa das manhãs ${ }^{8}$ em que me desloquei ao matadouro, Júlia (Departamento de Qualidade) mencionou que seriam abatidos 65 porcos, que... "é pouco. [E que] é mais um dia..." de trabalho onde se abatem centenas por dia, por mês, milhares por ano.

5 De maneira a manter o anonimato do matadouro inquirido. a fonte não pode ser revelada.

6 Expressões facilmente observáveis nos relatórios, disponíveis online, do setor da agropecuária portuguesa.

7 Comparativamente, existem "linhas de abate" muito mais letais, as quais, por exemplo, podem abater mais de 1000 porcos em 60 minutos.

8 Na manhã de 24 de abril de 2019 estavam na "linha" 19 trabalhadores (18 homens + uma mulher). A Júlia, do Departamento de Qualidade, acompanhou-me durante todo o processo de observação e registo. 


\section{Transporte e descarga}

Não assisti ao "transporte" e à "descarga" dos animais para as "abegoarias". Mas esta constitui-se numa situação nova para os animais que, devido a vários fatores (e.g.: ruído, vibrações, alterações de velocidade do veículo, duração das viagens, e porque se encontram em lotes), os sujeita ao medo, stresse físico e emocional, lesões (e.g.: hematomas, arranhões, fraturas ósseas, stresse), e mesmo à morte (cf. Meliciano, 2011:21).

Quando entrei no perímetro do matadouro, os primeiros animais estavam a ser "encaminhados" das "abegoarias" para as "mangas" (ver figuras 4 a 6 em anexo). Os seus histéricos berros e grunhidos ${ }^{9}$ tornaram-se mais intensos após abrir a porta do carro. A Júlia (Departamento de Qualidade) direcionou-me para um pequeno gabinete onde me deu proteções de plástico para pés, corpo e cabeça (ver figura 19). À medida que caminhávamos em direção à "linha", Júlia sublinhara, e procurara justificar, o (audível e observável) horror que era experienciado pelos animais: "Eles hoje estão a berrar muito. O meu colega da abegoaria disse-me que estes animais estão bastante stressados. Pode ser do transporte."

\section{Encaminhamento}

O início da linha é que é mais complicado. [Júlia, Departamento de Qualidade]

Porque fui imediatamente direcionado para a zona entre a "manga" e a máquina de "atordoamento", não assisti ao "encaminhamento" dos suínos: fase particularmente violenta para os animais, e perigosa para trabalhadores. Foram visíveis, e audíveis, as violentas pancadas nos animais (ver figura 17) que se recusassem a ser direcionados para a "manga" (ver figuras 5 e 6). Foi-me confirmado o que era evidente: "Todos os animais têm marcas por causa do transporte, em que se mordem uns aos outros, ou por causa do encaminhamento," [Júlia, Departamento de Qualidade).

Porque na "linha" os animais devem ocupar uma determinada distância, uns em relação aos outros, o ritmo do "encaminhamento" é importante, daí as pancadas serem constantes, sobretudo naqueles que mais resistem. A Diretiva n. ${ }^{-93 / 119 / C E}$ (22 de dezembro) relativa à "proteção dos animais no abate e/ou occisão" assevera ser "proibido espancar os animais [...] e [que] são proibidas as pancadas aplicadas com brutalidade, designadamente os pontapés". Mas o uso destes procedimentos é inevitável durante o "encaminhamento" dos animais que, efetivamente, têm frequentes e agitadas reações de fuga, constituindo-se também num perigo para os próprios trabalhadores encarregados desta etapa.

9 O termo eufémico "vocalizações" é reiteradamente usado em artigos oficiais do setor da agropecuária. 


\section{Atordoamento}

Ambas as técnicas de qualidade preveniram-me que a "insensibilização" é das fases mais difíceis de serem (visualmente) experienciadas. No interior da "manga", o medo estava estampado nos olhos dos animais, que procuraram afastar-se do equipamento automático de "atordoamento" (restrainer em "V"). Conforme a figura 5, um trabalhador permanece nesta zona para assegurar que os animais entram no aparelho de "atordoamento", e que uma determinada distância é mantida. Forçados, entram em fila no equipamento que os comprime, enquanto estão suspensos, e que ao longo da superfície liberta água juntamente com cargas elétricas (ver figura 7). O "atordoamento" realizado por electrocução é automático, e deve levar os animais a caírem inconscientes no tapete e passarem para a fase da "pendura". É a etapa do "atordoamento", que dura aproximadamente vinte segundos, que antecede a "pendura" e a morte ("sangria"). Quando o aparelho automático falha, e caso esteja um funcionário perto, o animal será sujeito ao "atordoamento" por eletronarcose manual (conforme a figura 8).

Júlia (Departamento de Qualidade), enquanto observava o processo de "atordoamento", preenchia um papel onde constavam critérios relativos ao "bem-estar" dos animais. Entre os vários termos técnicos que constavam na folha, "pedaladas" era um dos mais facilmente interpretável. Ou seja, se os animais "pedalassem" (sobretudo com as patas traseiras) não estariam a ser cumpridos os requisitos mínimos de "bem-estar" animal. Em entrevista, um dos funcionários confirmara-me que, de acordo com a sua experiência, "alguns porcos, ainda a sangrar, ficam a andar de bicicleta" [Alberto], que "pedalam" - o que pressupõe que não é incomum os animais permanecerem indevidamente "atordoados" até chegarem à "sangria". Do tempo que permaneci na zona onde se faz o "atordoamento" e a "pendura" (ver figura 2), observei muitos animais a "pedalarem", com os olhos congelados de pânico, após saírem do aparelho de "atordoamento".

Mas também foi observado (e documentado) que outros animais não foram atordoados pelo aparelho automático, caindo conscientes no tapete. Estes animais, que conseguiam ver os outros da frente a serem pendurados e sangrados, procuraram freneticamente escapar do tapete rolante (ver figuras 10 e 11). Este foi também um momento de particular tensão para os trabalhadores desta zona da "linha", que devia estar coordenada, com o devido timing. Alguns destes animais foram "atordoados" manualmente no chão. Outros, à pancada, tiveram de ser novamente "reencaminhados" para uma das "abegoarias", entrar pela "manga", e ser de novo sujeitos ao "atordoamento" automático. Após a situação ficar controlada, Júlia diz-me, algo tensa e embaraçada: "Aquele episódio de há bocadinho foi muito desagradável" [...] o que aconteceu há pouco não é muito normal. Os animais estavam muito stressados."

\section{Pendura}

"A parte da pendura é muito perigosa" (Júlia, Departamento de Qualidade) porque os animais podem acordar e, com movimentos bruscos, magoar os trabalhadores. Nesta etapa um funcionário prende uma corrente numa pata traseira do animal 


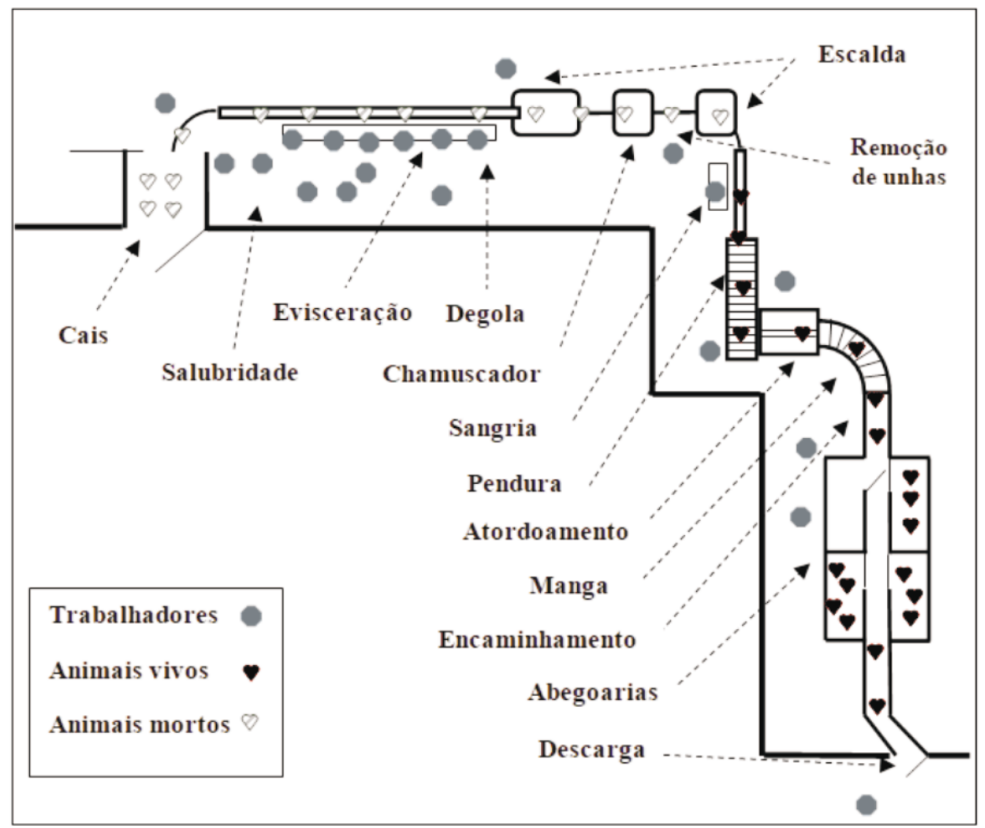

Figura 2 A "linha de abate" observada, disposição dos trabalhadores e percurso dos suínos

que, através de um sistema automático de roldanas, o suspende de cabeça para baixo e o transporta até ao próximo trabalhador que fará a "sangria".

\section{Sangria}

É nesta etapa que os animais são mortos, e é a partir dela que os gestos dos trabalhadores da "linha" se tornam cada vez mais mecanizados e monótonos. O trabalhador da "sangria", elevado numa plataforma e a cerca de um metro do chão, faz o golpe no pescoço dos animais, acedendo às veias jugulares e artérias carótidas (ver figuras 12 e 13). Enquanto os animais estão pendurados e vão morrendo, muito do sangue é drenado através de uma mangueira, outro vai caindo para o tanque.

\section{Escaldas, remoção de unhas, chamuscador}

Já mortos, os animais, seguem em fila pelas roldanas para o primeiro "banho" quente, onde escovas ajudam a remover o sangue e a sujidade dos corpos. Um outro trabalhador volta a posicioná-los na horizontal e remove-lhes as unhas (ver figura 14). Posteriormente, espeta um gancho nas duas patas traseiras, volta a suspende-los no sistema de roldanas que os transporta para o "chamuscador" (ver figura 15), onde os pelos são queimados / removidos. Na etapa seguinte os animais são novamente sujeitos a jatos de água quente. Na zona entre a "sangria" e o "chamuscador" (ver figura 2) as 
temperaturas são particularmente elevadas: existe muita humidade, vapor, e a circulação de pessoas nesta zona implica que tenham de passar entre os corpos dos animais suspensos (e, até, esbarrar neles).

\section{Degola, evisceração, salubridade e cais}

Grande parte dos trabalhadores estão posicionados em linha reta na zona da "degola" até ao "cais" (ver figuras 2, 16, 17, 18). Sem terem qualquer acesso aos processos de matança, lidam com as incisões nos corpos dos animais: removem e separam línguas, corações, pulmões, rins, tripas, estômagos, separam as vísceras, e identificam os corpos. Apenas nesta zona foi vislumbrado um veterinário a retirar amostras dos fígados para a realização de análises. Os corpos dos animais são depois longitudinalmente serrados por uma serra mecânica suspensa, orientada por um trabalhador. Após divididos em dois, os animais são carimbados manualmente, levados para o armazém / cais, onde permanecem aglomerados em baixas temperaturas, para depois serem recolhidos por transportes que os levam a comércios locais.

\section{As atitudes dos trabalhadores da "linha" para com os animais}

\section{Metas produtivas e a obrigatoriedade do abate}

Não é um trabalho fácil. Eles [trabalhadores] [...] têm de conseguir. Quem não quer, ou não consegue, entra pela porta e sai diretamente pelo cais. [Cátia, Departamento de Qualidade]

As condições e as metas produtivas exigidas pela classe dirigente (e.g.: empresários, gestores, diretores, etc.) constituem-se num contributo fundamental na edificação das atitudes dos trabalhadores que operam na "linha", mas também apresentam evidentes repercussões nos animais. Quem trabalha na "linha" do matadouro tem de cumprir as tarefas delimitadas, o que implica que todos os animais que entram têm de ser mortos e sujeitos à "desmancha". Mesmo que alguns trabalhadores responsáveis pela "sangria" tenham dificuldades em abater um determinado animal (e.g.: um cavalo, ou um boi que chore na "linha" - casos verbalizados nas entrevistas), as respetivas tarefas terão de ser delegadas a colegas.

\section{Estratégias para a exequibilidade do abate de animais}

Para lidar com estas coisas eles esquecem que os animais têm sentimentos, e até convém. [Júlia, Departamento de Qualidade]

A parte que custa mais é o início do processo, quando entram na manga para serem insensibilizados. Eu ponho na minha mente que eles não sabem que vão ser mortos. [Júlia]

Eu gosto muito de animais, mas a gente não pode pensar... [Alberto]

Abater é como quem faz um casaco. [Alberto] 
O ser humano sempre fez isto. Eu digo isto a mim própria para lidar bem com isto. [Júlia]

Tento pensar que é o meu trabalho, que estou ali para controlar e minimizar o sofrimento dos animais. Dentro de todos os males, isto é um bem. Tento evitar olhar os animais nos olhos, sobretudo bovinos. [Júlia]

Em qualquer contexto empresarial onde prevaleça o realismo comercial, a força de trabalho tem de estar assegurada com o fim de serem atingidas determinadas metas produtivas. Em qualquer matadouro, a realização das tarefas violentas relacionadas com o abate está dependente de um trabalho interno que tem de ser operacionalizado por quem está na "linha", e que envolve: objetificação, desapego, distanciamento, designadamente racionalizações em relação aos animais (ver figura 3). Para os trabalhadores de um matadouro, a não criação de eventuais mecanismos de empatia e solidariedade para com os animais facilita a execução de tarefas relacionadas com os processos de "abate". Adicionalmente, também permite atenuar algum desconforto cognitivo, moral, emocional que possam experienciar durante a sua rotina laboral.

Reconhecimento dos animais enquanto seres sensíveis

A gente tem de pensar que é um animal que tem sentimentos. [Alberto]

Os bois também choram. Cheiram o sangue e estrebucham. [Francisco]

Na linha de abate o boi da frente é abatido e o de trás chora. É o instinto. [Alberto]

Há alguns animais que já me levaram assim com brincadeiras. Uma vez um boi foi insensibilizado, acordou e pôs-se a correr na linha de abate. Parecia que estava a fingir. Depois foi apanhado e foi abatido. [Alberto]

Um assunto um pouco difícil de lidar. Há momentos que não são fáceis. [Júlia]

Eles têm o olfato melhor que o nosso. Eles sabem que lhes vai acontecer alguma coisa. [Júlia]

Eles choram. Os porcos também berram muito. [Júlia]

As atitudes dos trabalhadores em relação aos animais que entram no matadouro apresentam um carácter essencialmente instrumental, não coexistindo com outras de carácter afetivo. Mas, embora os animais permaneçam num estatuto de permanente objetificação (ver figura 3), não quer dizer que os trabalhadores não os reconheçam como seres individuais, sencientes e que, simultaneamente, têm de ser tratados como meros produtos a dispor e destruir.

\section{Afetos diferenciados em relação aos animais}

Tinha lá em casa o porco "Francisco", um ano e meio, esse foi abatido mas nem olhei, Ele ia com nós a passear. [Luís]

Criar um animal e matar é mais difícil. [César] 


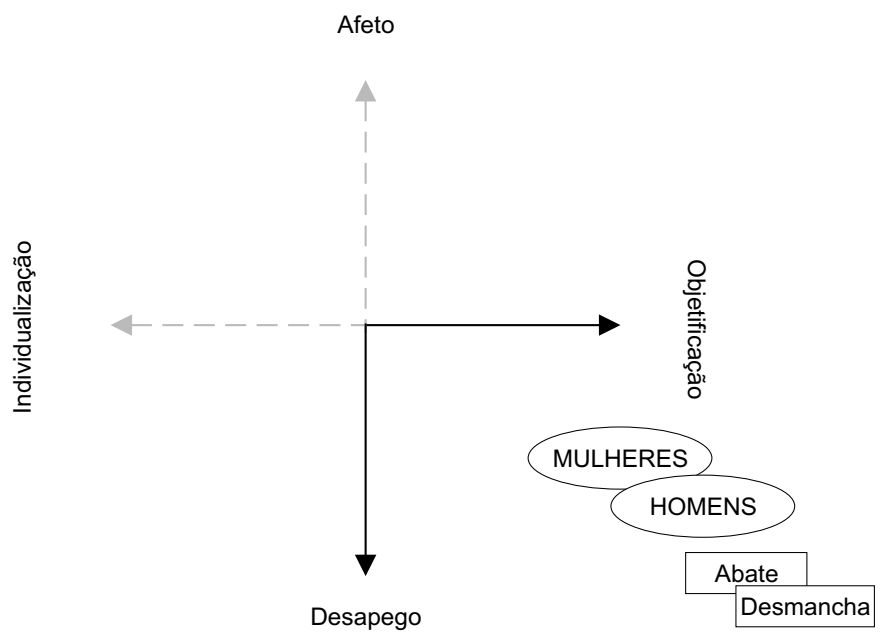

Figura 3 Status dos animais e atitudes predominantes (consoante o género) durante o abate e desmancha

O cavalo é que custa matar. Uma vez estava um cavalo na manga para morrer e estava a chorar. Parecia que estava a adivinhar. [Francisco]

Uma porca da minha mãe andava atrás dela e depois eu tive de a matar. Custou. [Francisco]

Os cabritos e os borregos andam [na produção do Francisco e do pai] ao nosso lado em nossa casa, a esses custa matar. [Francisco]

O que me mete impressão são os porcos que ainda chiam. Os bois caem logo para o lado. [César]

Coelhos não gosto de ver abater. - Porque são fofinhos? -Sim. [risos] [Luís]

O boi nem consigo ver [abater]. O boi transmite-nos mais emoções. O porco já não, Entra na manga e não cria esta emoção. [Cátia]

Sou contra baterem num cão. Se fizerem isso à minha frente bato na pessoa [risos]. [Alberto]

Os cavalos não deviam ser abatidos. [Alberto]

Uma vez um cavalo fugiu aqui, apanhei-o, montei-o e depois teve de ser abatido e não olhei. [Alberto]

Na produção do meu pai, às vezes custava mais. Agente dava-lhes nomes. [Francisco]

Apesar de praticamente todos os trabalhadores inquiridos da "linha" terem adquirido, desde a infância, a experiência com o abate, muitos deles verbalizaram sentimentos de desconforto com a morte de determinados animais. Podem estar 
associados a fatores de ordem ideológica (i.e.: especismo), reconhecimento de determinados animais como indivíduos, tempo passado e experiências com determinados animais.

\section{A velocidade na linha e a fugacidade de tempo entre trabalhadores e animais}

Assim que dão entrada no matadouro os animais podem permanecer nas "abegoarias" algumas horas, ou mesmo ser imediatamente encaminhados para o "atordoamento". Já na "linha", o tempo que os animais permanecem vivos pode durar minutos, e o tempo que cada um deles passa com cada trabalhador pode durar segundos. Além do mais, porque surgem em grande número ("lotes"), os animais têm um tratamento mais desindividualizado. Estes dois fatores, contribuem para reduzir as hipóteses de serem criadas quaisquer relações de afeto entre trabalhadores e animais.

\section{Evitar acidentes e lesões com a polivalência}

Uma vez a máquina fugiu a um homem e ele cortou um dedo. Outro homem está em casa por ter as costas todas desfeitas, por andar a cortar durante tantos anos. [Aníbal]

A gente tem de fazer de tudo, dar tiro nos bois, espetar nos bois, como nos porcos. [Marco]

Nós trocamos de tarefas. Não há monotonia. [Alberto]

Temos de nos ajudar uns aos outros. Ao fim do dia o trabalho tem de ser feito. [Alberto]

Num matadouro repleto de animais experiencia-se um ambiente frenético, que também combina pessoas, ferramentas afiadas, máquinas pesadas e automatizadas. Os funcionários estão conscientes da natureza perigosa do seu trabalho. Os que fazem o "maneio" dos animais vivos (na "abegoaria" - "manga" - "atordoamento" - "pendura") têm de lidar com comportamentos imprevisíveis dos animais de grande porte. Os que operam com os animais já mortos fazem uso de ferramentas cortantes, e exibiram movimentos corporais repetitivos, monótonos. A combinação de longas horas de trabalho com a monotonia, aumenta o risco de lesões: dores crónicas nas mãos, pulsos, braços, ombros e costas. Devido à natureza repetitiva e entediante dos processos de trabalho, os trabalhadores usualmente optam pela troca de posições (polivalência) na "linha".

O trabalho da "sangria"

Nem toda a gente vai para a sangria. Só dois ou três o fazem. [Júlia, Departamento de Qualidade] 
Não é fácil fazer isto, nem todos podem fazer. [Aníbal]

Já matei milhares. [Francisco]

Aos primeiros custava. Às vezes a faca ia mal e o animal guinchava. [Francisco]

Para mim, por ser todos os dias, tornou-se fácil. [Luís]

Isto para mim não tem problemas. Mas para quem nunca viu isto mete impressão. [César]

Tive que me habituar. [Marco]

Apesar de quase todos os funcionários da "linha" terem já muita experiência e serem capazes de lidar com a "sangria" dos animais "não quer dizer que depois, tecnicamente, o façam corretamente". É uma "etapa importante que exige prática para desempenhar a tarefa [...] apenas dois ou três funcionários a poderão desempenhar, desde que tenham previamente um período de prática para a concretizar com a máxima segurança e técnica" (Departamento de Qualidade). Portanto, mais que a prática, o abate dos animais requer a aquisição dos movimentos mais "corretos" para os sangrar. A frieza, ou a ausência de emoções, e o foco na técnica de como "meter a faca" pode atenuar o sofrimento dos animais envolvidos. No matadouro inquirido, normalmente é o encarregado juntamente com a administração quem decide quem terá a "formação" e quem estará apto a abater os animais.

Trajetórias laborais: socialização das práticas de matança de animais

Os relatos de todos os trabalhadores inquiridos dão indicações de que o seu percurso laboral apresenta uma estreita relação com processos de socialização mais tradicionais que tiveram, e ainda têm, lugar em determinadas zonas rurais ou periféricas do país. Todos os trabalhadores (homens) inquiridos da "linha", com exceção de um, foram incentivados na infância, por outros homens, pela observação direta e pela prática, a lidar com o abate de animais: ${ }^{10}$

O Marco (magarefe, polivalente), por influência do tio e de outros familiares mais velhos, lida com o abate de animais, designadamente suínos, desde os 15 anos. Tem uma pequena produção e, quando solicitado, mata "o porco, também cabritos, a particulares". O César (magarefe, polivalente) é um dos trabalhadores que há mais tempo está no matadouro - abate "o que for preciso: bois, porcos, cavalos, ajuda a matar borregos, pendurar, segurar e puxar peles". Começou a lidar com a matança de animais em criança. O Francisco (magarefe,

10 Inclusivamente, dos três elementos da direção, "dois deles herdaram o negócio dos pais/familiares (homens)" (Departamento de Qualidade do matadouro). 
polivalente), um dos trabalhadores mais antigos, está no matadouro há 18 anos, Já abateu "milhares". Por influência do tio e do pai, começou a matar porcos e borregos aos 14 anos na pequena produção familiar (do pai). O mais jovem trabalhador inquirido, Luís (magarefe, polivalente), está no matadouro desde os 16 - "dá choques a borregos, corta patas, tira peles, salga couros". Por influência do tio, "lida" com os animais desde pequeno. O Alberto ("abegoaria", polivalente) trabalha no matadouro há quatro anos. Faz o "encaminhamento" e, casualmente, ajuda na "insensibilização" dos animais. Por influência do avô, que tinha uma pequena produção, "aos cinco ou sete anos já matava coelhos" e aos 15, com a ajuda do pai, tio e avô, abateu o seu primeiro porco. O Aníbal (motorista, polivalente) trabalha no matadouro e lida com os animais há seis meses, também os transporta (convertidos em "carcaças" para clientes. Este foi o único inquirido do sexo masculino que não foi habituado desde a infância a lidar com o maneio e abate dos animais. Pela sua experiência confessou a sua dificuldade em lidar diariamente com o seu trabalho, particularmente em "usar a serra para cortar o boi", um trabalho pesado que considera "difícil", e que há pouco tempo teve de delegar a outro colega. Em sua defesa, ou em defesa da sua masculinidade, o Aníbal afirmara que "não se deixa de ser homem por achar isto difícil".

Das duas mulheres inquiridas que supervisionam, mas não operam, (n)a "linha de abate" - Cátia (engenheira alimentar) tem um pai produtor e um padrinho talhante; e a Júlia (engenheira alimentar) apenas começou a lidar com animais há dois anos, neste mesmo matadouro. ${ }^{11}$

Os relatos biográficos de praticamente todos os trabalhadores (homens) inquiridos dão claras indicações de que os seus percursos laborais resultam, em grande parte, de aprendizagens adquiridas através de outras figuras masculinas (pais, avôs, tios) em contextos de exploração animal, do tipo produção familiar e pequena produção. Mesmo em relação a outros trabalhadores da "linha", que não foram entrevistados, o próprio Departamento de Qualidade do matadouro assinalou a existência de "influências familiares no que diz respeito ao abate de animais. As famílias deles tiveram/têm quintas com animais para consumo próprio".

Se, por hipótese, a ordem social inscrita nestes contextos familiares de produção animal, onde os inquiridos cresceram, apresentar um previsível carácter tradicional, então neles vigora uma determinada doutrina, que se repercute nos indivíduos humanos (homens, mulheres e crianças), nos respetivos papéis de género, nas perceções, nas formas de sentir, nas verbalizações (e falta delas) e, consequentemente, nas práticas de maneio / abate dos animais. Particularmente nas produções domésticas, onde animais são criados para consumo, a divisão sexual do trabalho é manifesta, ${ }^{12}$ cabendo às mulheres (mais limitadas ao espaço doméstico) alimentar os animais, eventualmente abater os de pequeno porte. Já os homens encarregam-se do abate dos animais de grande porte, os que oferecem mais resistência, que propiciam mais prestígio aquando da sua morte (Méchin, 1991), Júlia (Departamento de Qualidade), confidenciara-me que

11 Aúnica mulher que opera na "linha", que não foi entrevistada, cumpre mais funções na triparia em substituição do marido que está lesionado devido a um acidente de trabalho.

12 Sobre a divisão sexual do trabalho inscrita em contextos de produção, consultar Fonseca (2019). 
"com os animais mais complicados de lidar eles [trabalhadores] parece que têm mais vontade de fazer o abate. Os mais dóceis para eles é mais complicado".

Os animais também surgem como extensões simbólicas de homens e rapazes, cujo abate permite a afirmação de um tipo de modelo de masculinidade "mais primitivo" (Rogers, 2008), Kheel (1996) explica que, em várias culturas, a matança de animais ainda representa um ritual simbólico que permite sequestrar os rapazes do mundo das mulheres - o espaço doméstico - e marcar a sua passagem para a vida adulta e, sempre por oposição a elas, construir um modelo de identidade masculina. Este é um fenómeno coletivizado, historicamente perpetuado em zonas rurais e periféricas, em que os homens mais velhos serão ainda compelidos (por pressão ou por motivação) a orientar os rapazes para abater os animais. Mas, embora praticamente todos os indivíduos da "linha" tenham sido socializados a lidar diretamente com o abate em contextos familiares, não quer dizer que estas ordens sociais não deixem de ser desafiadas, e mesmo abandonadas, por outros indivíduos. ${ }^{13}$

Foi relatada pelo Departamento de Qualidade do matadouro, que normalmente faz o acompanhamento no recrutamento de novos trabalhadores, a existência de casos de candidatos que entraram na "linha" e saíram diretamente pelo "cais", sem nunca mais voltarem. Esta inadaptabilidade para lidar diretamente com a morte dos animais foi explicada, por uma das técnicas de qualidade, por se tratar de "casos de pessoas que, durante a infância, não tiveram contacto com esta realidade [do abate]".

Embora não existam estatísticas publicadas sobre outros centros de abate em Portugal, estima-se que também cá poderá existir o recrutamento de trabalhadores originários de comunidades imigratórias mais desfavorecidas, que necessitam de meios económicos e que têm, forçosamente, de cumprir as suas funções, mesmo que não gostem. Contudo, as percentagens de imigração na força de trabalho em matadouros portugueses poderá estar bem mais abaixo dos $38 \%$ nos EUA, onde é sobretudo composta por latino-americanos e afro-americanos (cf. Engdahl, 2005). A ocupação de um posto de trabalho numa "linha de abate" também pode ser motivada pela necessidade de qualquer individuo, com baixas qualificações, pretender colmatar carências económicas; ou ainda, em alguns casos, "estar relacionada com a personalidade da pessoa" (Departamento de Qualidade do matadouro) - pelo desejo de experiência da adrenalina, ou mesmo do princípio de prazer, aquando da morte dos animais. ${ }^{14}$

13 Por exemplo, um outro proprietário de um matadouro de leitões (Baguim do Monte), chegou a relatar que levava dois dos seus filhos ao matadouro, e que "eles fechavam os vidros por causa dos berros dos bichos. O [terceiro] mais velho já não é assim", chegando, aliás, a codirigir o negócio com o pai. Este caso demonstra que os modelos masculinos não têm de ter um inevitável carácter normativo, podendo ser abandonados.

14 Contudo, o prazer ou a adrenalina derivados de exercer a morte sobre um animal pode atenuar-se quando o ato em si se torna rotineiro, serial, automático e meramente gestual. 


\section{Considerações finais}

Este artigo é um contributo para os estudos (críticos) sobre as interações entre humanos e animais. É um snapshot acerca da natureza das atitudes e das práticas de indivíduos que trabalham num (anónimo) matadouro português. Também ministra uma compreensão acerca da estrutura organizacional (i.e.: a divisão sexual do trabalho), aspetos ideológicos e legais legitimadores da exploração de animais. Há uma, mais ou menos evidente (antropocêntrica) ${ }^{15}$ premissa ideológica, que sustenta as atitudes inquiridas e práticas observadas: que as espécies suínas, entre outras, são constituíveis enquanto recursos, propriedade, comida. Este enquadramento ideológico, geralmente percecionado como inquestionável e incontestável, é geracionalmente inculcado, amplamente internalizado, institucionalizado, reforçado pelas representações e pelas práticas de consumo.

$\mathrm{Na}$ contemporaneidade a matança maciça de animais é, simultaneamente, mais intensificada e mais recôndita que nunca. Um curioso consumidor, ou mesmo um investigador que não atue alinhado com os interesses do agronegócio, muito dificilmente poderá entrar num matadouro. Lá dentro, num dia normal de trabalho, sensações como pena, horror, desgosto, choque, repugnância, entre outras, são facilmente experienciáveis. Mas a manutenção do atual status quo do sistema de exploração de animais para fins alimentares estará dependente do impedimento de que estas sensações sejam experienciadas pelos consumidores. É um "mundo fechado" - dizia um proprietário de um outro matadouro - provavelmente porque existe uma noção de que a manutenção das práticas de consumo depende da omissão das práticas de maneio e de abate a que os animais estão sujeitos. Ou seja, será conveniente, para o setor exploratório, que o desconhecimento, desinteresse e a indiferença dos consumidores se mantenham em relação aos animais. Para o efeito, será fundamental que os animais continuem a ser concebidos pelos consumidores enquanto "referenciais ausentes" (Adams, 2003) (e.g.: "carne", "bitoques", "chouriços", "presunto", etc.), e que se evitem cogitações sobre os processos a que estão sujeitos durante a sua vida e morte.

Já para os indivíduos da "linha", a indiferença, a objetificação e o desapego constituem-se como atitudes estratégicas (algumas verbalizadas), que permitem a operacionalização das tarefas relacionadas com o "abate" e "desmancha" dos animais. Adicionalmente, o contexto laboral (i.e.: o matadouro), o tipo de práticas estipuladas pela classe dirigente, a legislação em vigor, as motivações económicas, sobretudo o género, consubstanciam-se como fatores influentes nas formas de atuação dos trabalhadores que lidam com os animais. Praticamente todos os trabalhadores da "linha" foram, durante a infância, orientados e encorajados, através da observação e prática, a participar em atividades que envolviam a exploração e a morte dos animais. Entram aqui em causa os scripts de género mais tradicionais, reproduzidos em contextos domésticos do interior ou periferia, em que o abate dos

15 Por se encarar determinado animal enquanto fonte de serviços para os humanos. Por exemplo, se proporciona benefícios económicos, se "dá" boas ninhadas, se "dá" boa "carne", etc. 
animais de grande porte surge como uma forma de conquista, de domínio "do homem sobre a besta", de afirmação de um tipo de modelo de masculinidade.

É no matadouro que a objetificação dos animais atinge o seu máximo grau, saltando à vista o seu estatuto ambíguo, em que são concebidos e tratados como coisas vivas, Foi observado, documentado, até verbalizado pelos trabalhadores e pelo Departamento de Qualidade, que os animais experienciam dor física, lesões, angústia, medo, frustração, stresse, durante o seu "encaminhamento", "pendura" e "atordoamento" - o que contraria qualquer tipo de premissa em relação ao seu "bem-estar".

Embora os trabalhadores façam uso da polivalência, trocando muitas vezes de funções na "linha", as suas tarefas acarretam riscos para a sua segurança: para aqueles que lidam com os comportamentos imprevisíveis dos animais vivos (sobretudo os de grande porte, quando experienciam situações de stresse); e para aqueles que lidam com os animais já mortos, cujas monótonas tarefas envolvem maquinaria pesada e objetos cortantes.

\section{Anexo 1: Outros excertos de entrevistas de trabalhadores do matadouro observado}

Marco, 51 - magarefe, polivalente

(Abate suínos desde os 15 anos por influência do tio. Desde essa idade que começou a trabalhar num outro matadouro. Tem pequena produção. Não tem receio de fazer trabalho nenhum,)

Os mais velhos ensinaram-me.

Às vezes mato o porco a particulares, também cabritos.

Mato bem o porco, sangra bem (sem errar).

Aníbal, 47 - motorista, polivalente.

(Trabalha no matadouro e lida com os animais há seis meses. Também os transporta para clientes.)

Não se deixa de ser homem por achar isto difícil.

Se me pedirem para matar vou lá, Usar a serra para mim é difícil.

Há pouco tempo pediram-me para cortar o boi e não consegui.

César, 57 - magarefe, polivalente

(Trabalha no matadouro há 19 anos. Começou a lidar com animais em criança, a matar galinhas, Ajuda a matar borregos, a pendurar, a segurar e a puxar peles. Abate bois, porcos, cavalos, o que for preciso)

Tenho mais medo de descarregar.

Francisco, 48 - magarefe, polivalente

(Trabalha no matadouro há 18 anos. Tem uma produção com o pai.)

Nasci com animais, com o meu pai a matar porcos e borregos.

Com catorze comecei a ir com o tio matar porcos.

Luís, 20 - magarefe, polivalente

(Desde pequeno que lida com os animais. No matadouro há quatro anos. Dá choques a borregos, corta patas, tira peles, salga couros, etc.)

Até aos oito tinha medo das galinhas.

Há mulheres que fazem este trabalho, mas é um bocado complicado. 


\section{Alberto, 26 - abegoaria, polivalente}

(No matadouro há quatro anos. Aos cinco ou sete já matava coelhos. É filho de caçador. Faz encaminhamento, às vezes ajuda na insensibilização e no matadouro. Lidou com os animais toda a vida, sobretudo por influência do avô que tinha produção familiar. Abateu o primeiro porco com o pai, avô e tio aos 15 anos. $\mathrm{O}$ avô ensinou.)

Um gajo tem que ter olho fino na abegoaria.

Há animais que parece que fingem sentimentos.

Alguns porcos, ainda a sangrar, ficam a andar de bicicleta.

\section{Cátia, 37 - engenheira alimentar}

(Trabalha no matadouro há oito anos como técnica de qualidade. O pai era produtor, o padrinho era talhante.)

Tratamos de tudo. Só trabalhamos com o pequenos comércio. Tratamos de burocracia, tratamos

e validamos as guias para o IFAP.

Vamos lá a baixo fazer o bem-estar animal.

Habituei-me a isto.

Agora tenho porco em casa, mas não quero matar.

$\mathrm{Na}$ linha de abate vê-se muita coisa.

Não sei se seria capaz [de abater].

Não me estava a ver a fazer isto.

Custa mais ver a insensibilização.

Os bois via, agora custa-me olhar para eles.

\section{Júlia, 28 - engenheira alimentar}

(Trabalha no matadouro há dois anos como técnica de qualidade. Começou a lidar com animais neste matadouro.)

Há registos obrigatórios na parte da insensibilização e não é fácil.

Tenho a certeza que eles sabem que thes vai acontecer alguma coisa.

O meu começo aqui foi complicado, Alguém tem que estar neste processo e lidar com isto.

O início da linha é que é mais complicado.

Vejo se não há excesso de quedas na parte da insensibilização.

Fazer a sangria seria mais difícil sem insensibilização.

Estares ali a avaliar aquilo é complicado.

Com os animais mais complicados de lidar eles [trabalhadores] parece que têm mais vontade de fazer o abate. Os mais dóceis para eles é mais complicado.

(Relatos da Júlia no dia 24 de abril de 2019; quando voltei ao matadouro assisti ao abate de 65 animais suínos)

65 porcos é pouco. É mais um dia..

Vou assegurar o bem-estar deles.

Eles hoje estão a berrar muito.

Todos os animais têm marcas por causa do transporte em que se mordem uns aos outros ou por causa do encaminhamento.

Muitos deles não ficam bem insensibilizados por causa das 'pedaladas'

Aquele episódio de há bocadinho foi muito desagradável [referia-se a alguns animais não ficarem

devidamente atordoados e tentarem fugir da sangria - ver imagens 7 e 8 em anexo]

Mas o que aconteceu há pouco não é muito normal. Os animais estavam muito stressados.

O meu colega da abegoaria disse-me que estes animais hoje estão bastante stressados. Pode ser do transporte.

Na linha de hoje há cerca de 20 trabalhadores. [Apenas uma mulher, esposa de um homem que estava magoado] A nossa linha tem capacidade para abater 100/120.

A parte da pendura é muito perigosa.

A parte da sangria é muito mecânica, mais previsível. Eles estão pendurados. 
Anexo 2 : Estatuto dos animais suínos em contexto de matadouro

\begin{tabular}{ll}
\hline & - Estatuto: "animais de produção"; objetificados; parte de grupo/lote \\
& - Motivações: somente comerciais, \\
& - "Encaminhamento" dos animais: apenas por homens \\
- "Pendura" e "sangria" dos animais: apenas por homens, & - Tempo previsto que cada trabalhador opera com cada animal (vivo): 30s máx, \\
& - Potenciais vinculos entre trabalhadores e animais: não existente. \\
\hline
\end{tabular}

\section{Anexo 3: Figuras documentais do processo de abate de animais suínos} na "linha" do matadouro

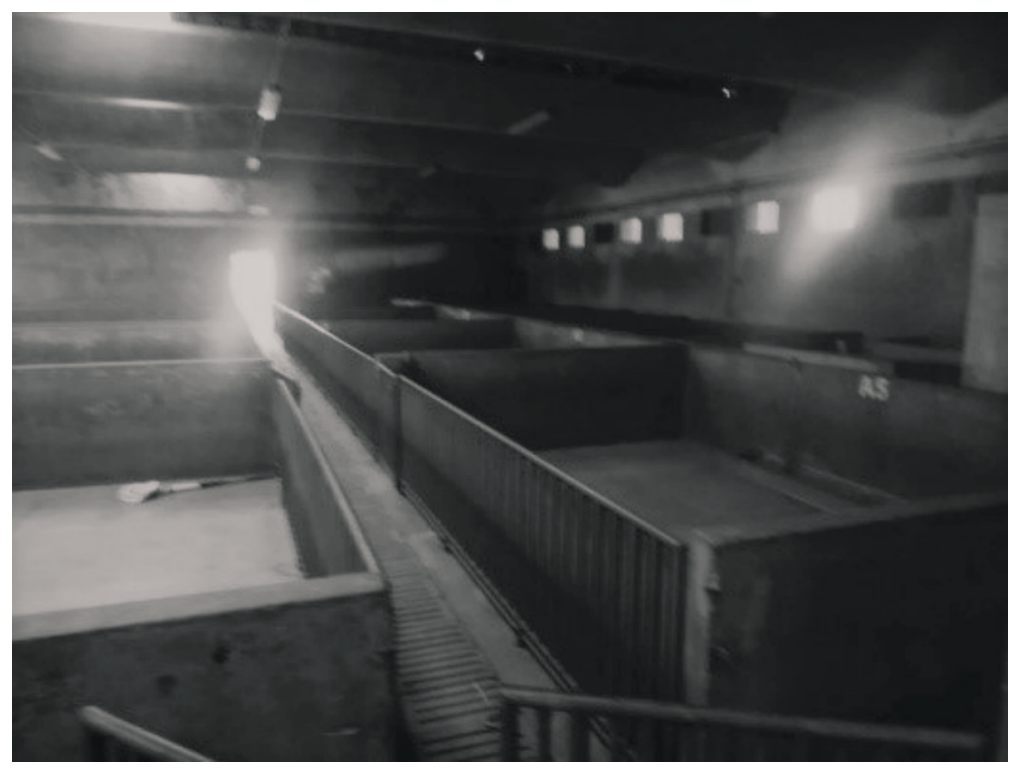

Figura 4 Abegoarias: onde os animais permanecem antes do abate 


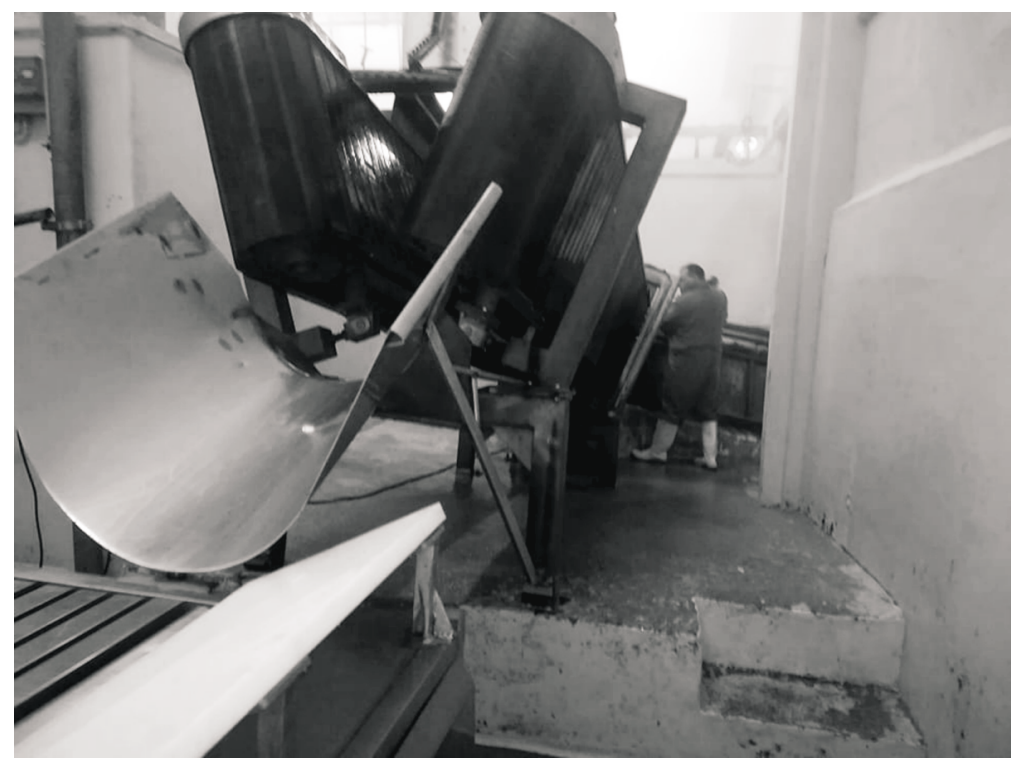

Figura 5 Encaminhamento dos animais para a o equipamento de insensibilização

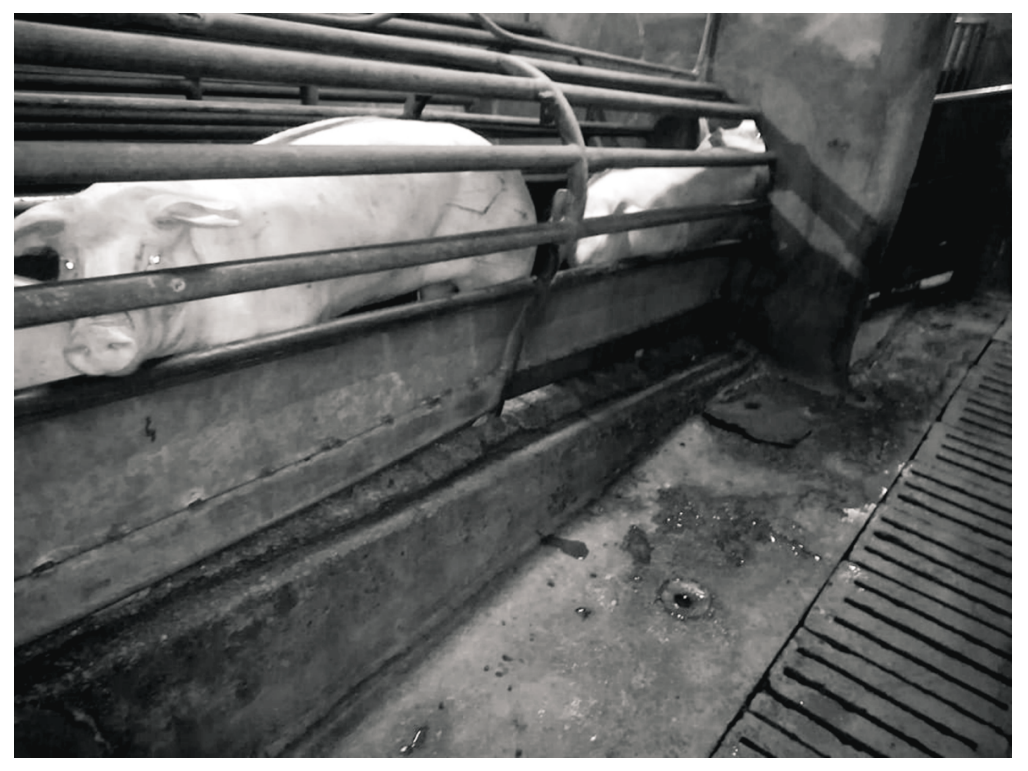

Figura 6 Animais nas mangas de encaminhamento 


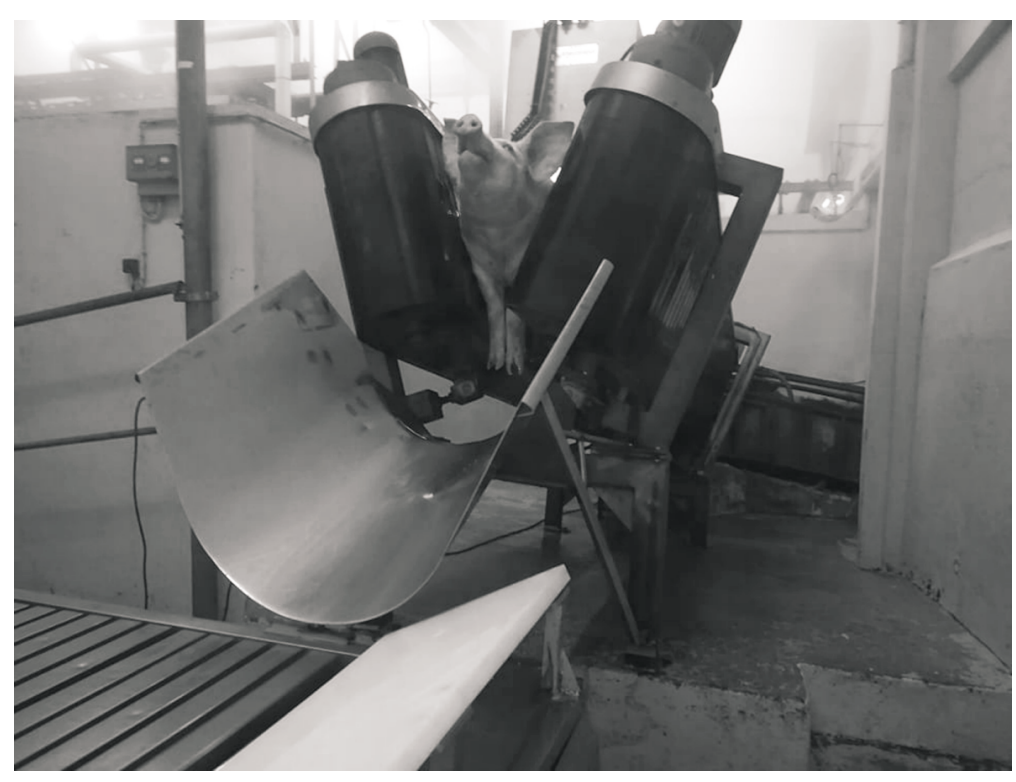

Figura 7 Atordoamento por eletronarcose

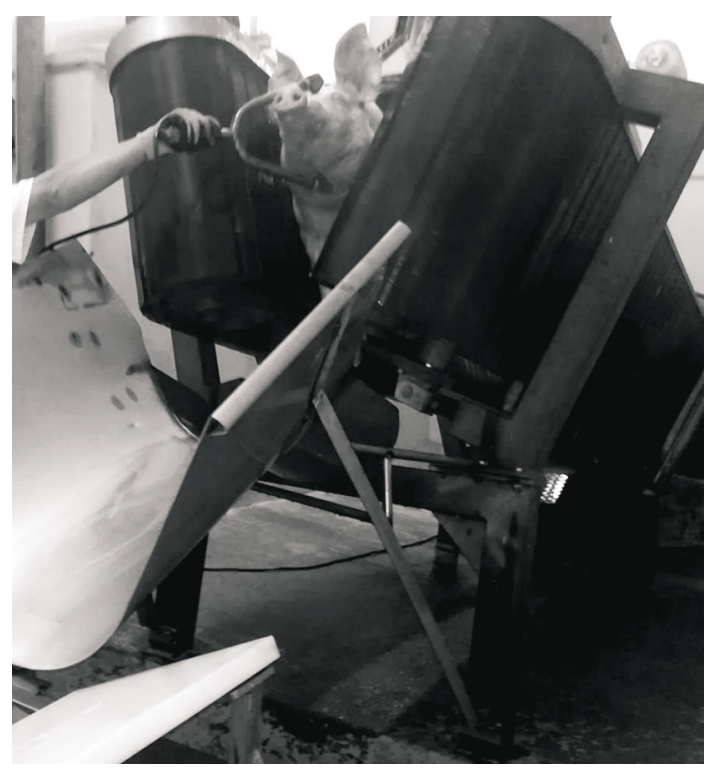

Figura 8 Atordoamento por electronarcose manual, em caso de falha do equipamento automático 


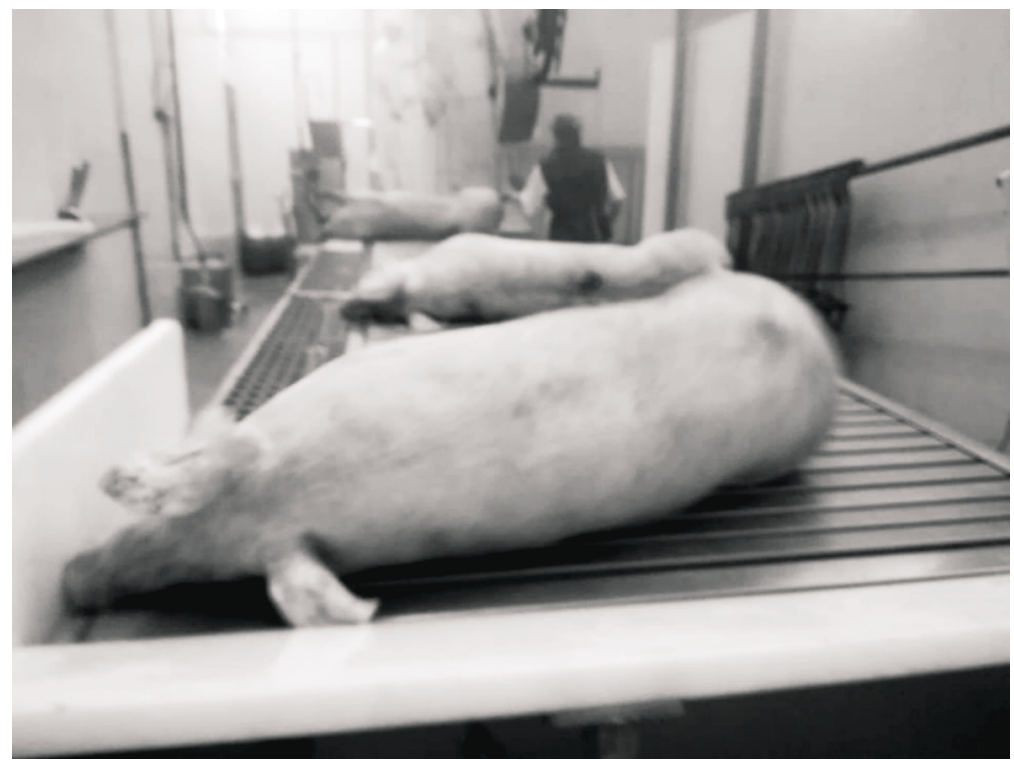

Figura 9

Animais atordoados no tapete rolante em direção à sangria

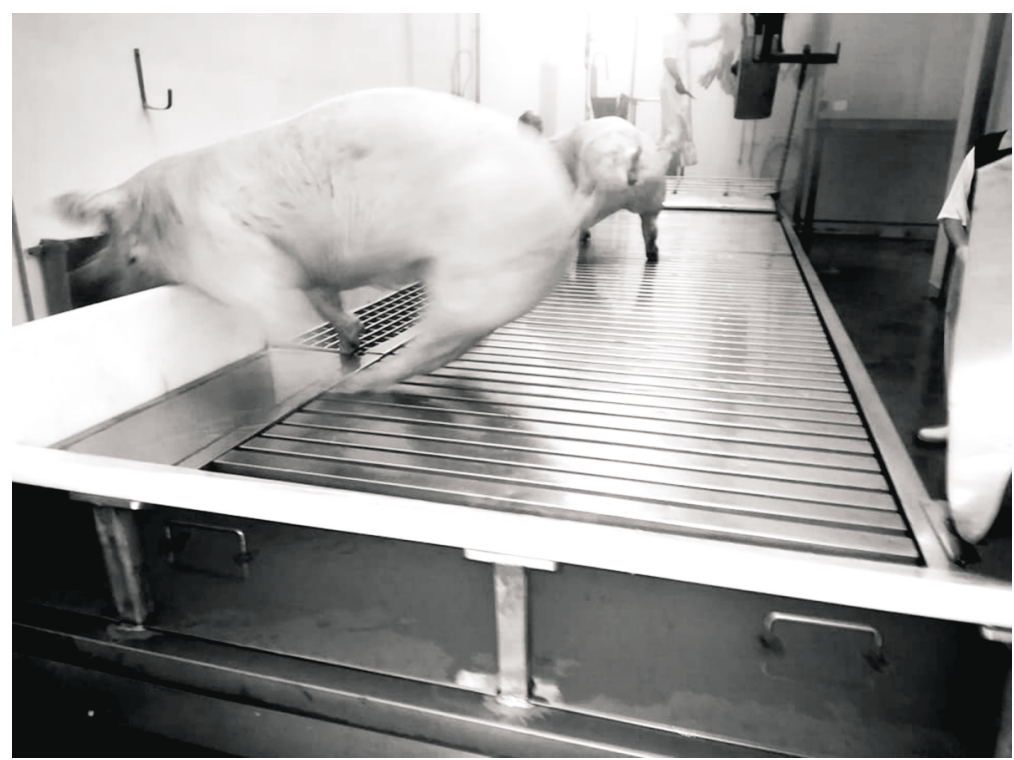

Figura 10 Animais não atordoados pelo equipamento automático, conscientes, a quererem escapar da sangria

SOCIOLOGIA, PROBLEMAS E PRÁTICAS, n.ำ92, 2020, pp. 81-109. DOI:10.7458/SPP20209218139 


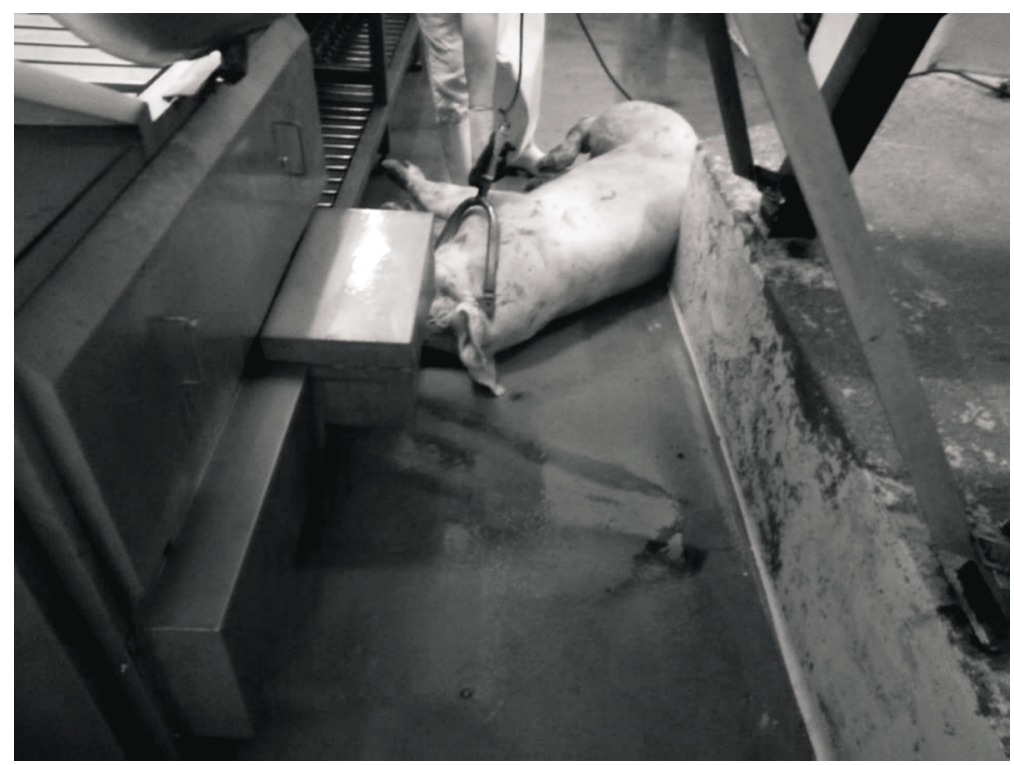

Figura 11 Um dos animais apanhados e atordoados (manualmente) no chão

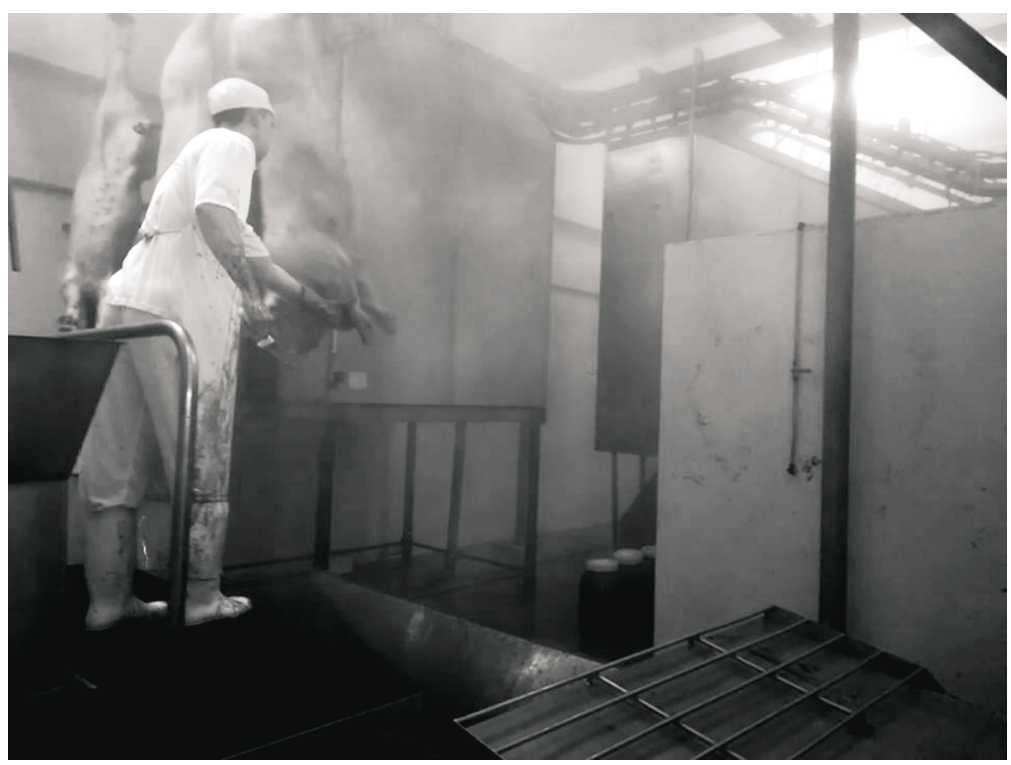

Figura 12 "Sangria" dos animais 


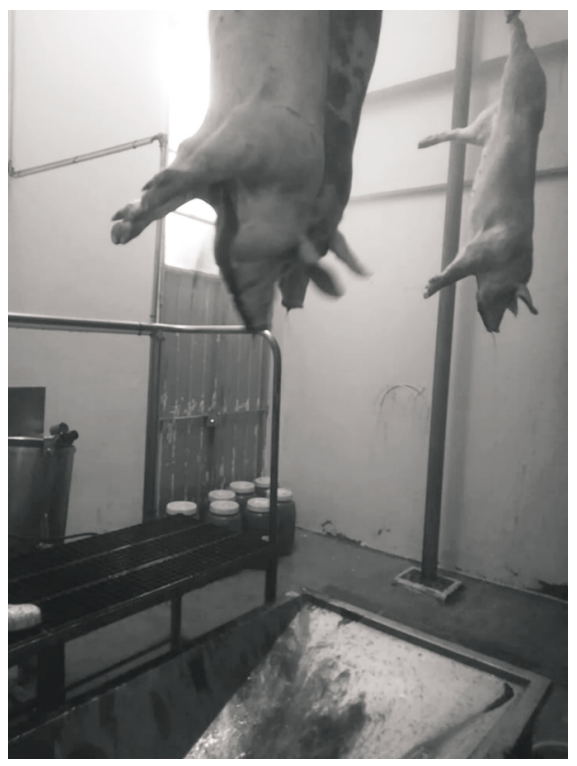

Figura 13 "Sangria" dos animais

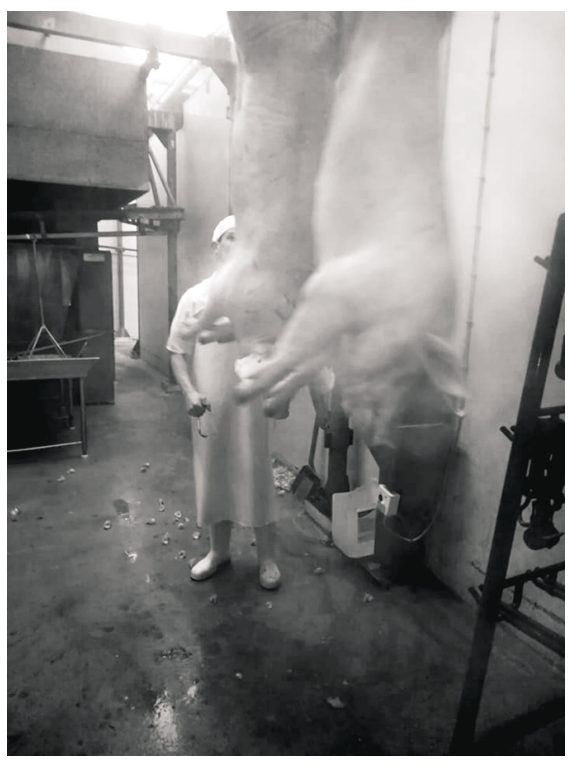

Figura 14 Remoção das unhas 


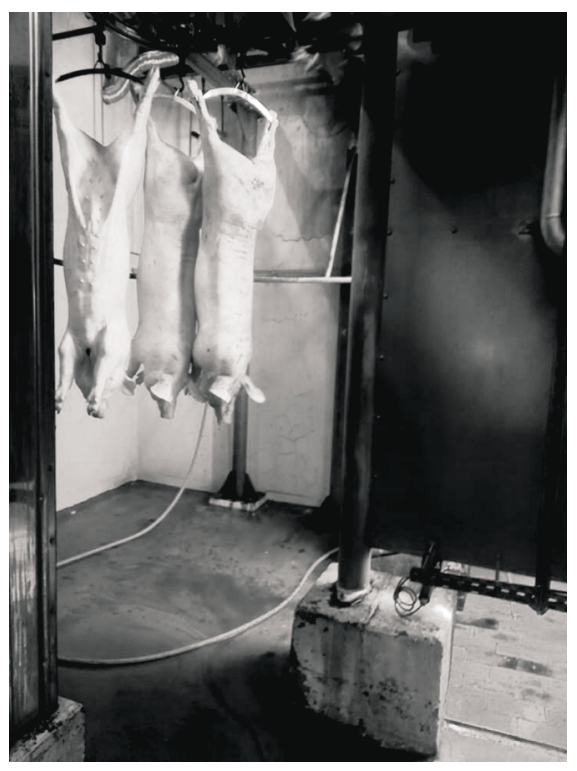

Figura 15 Entrada das "carcaças" no chamuscador

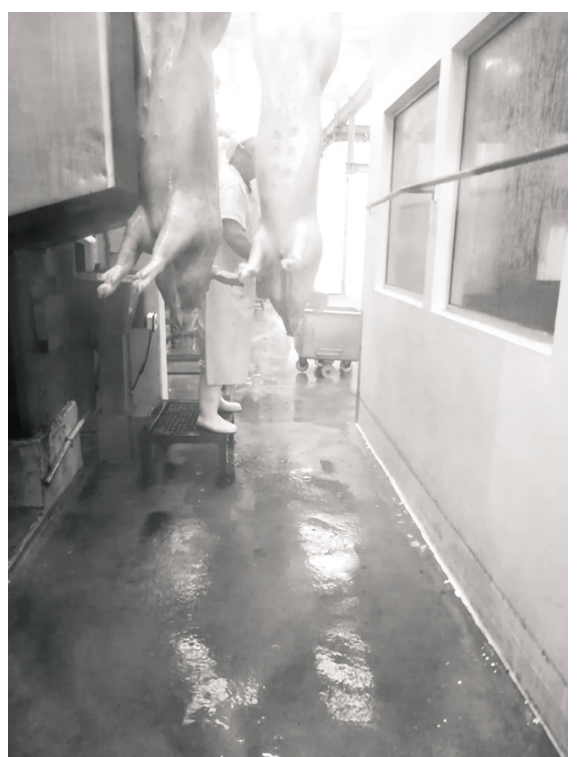

Figura 16 Degola e identificação da "carcaça” (número de ordem e cliente) 


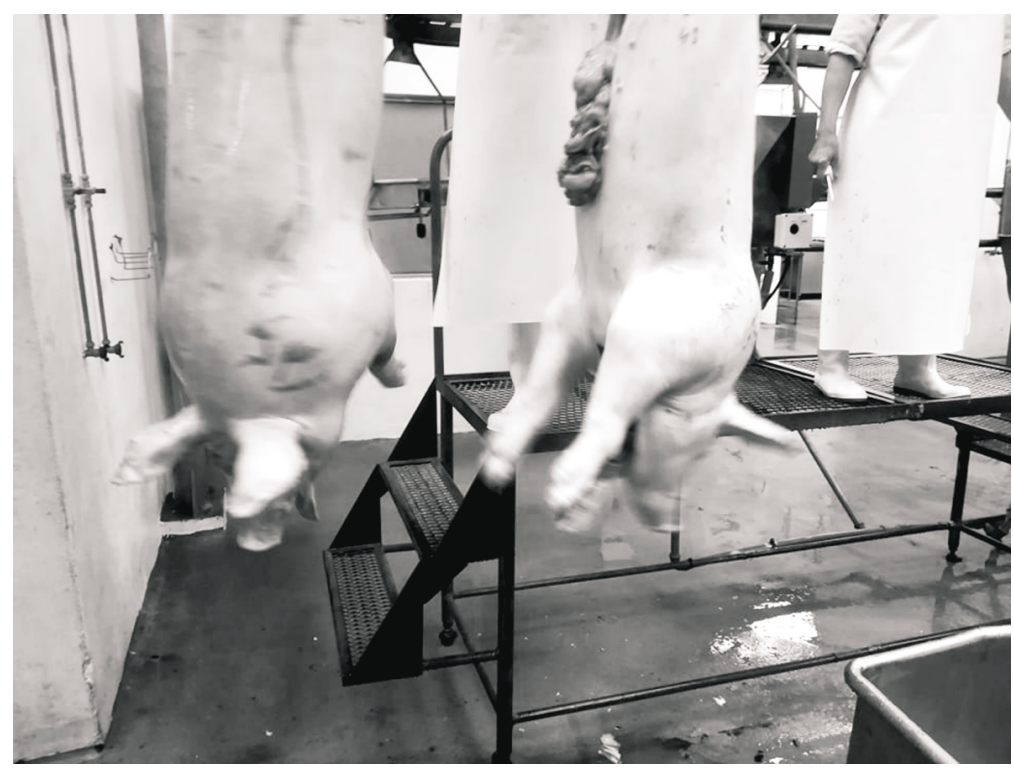

Figura 17 Início da "evisceração", (Nesta imagem são observáveis as marcas de mordidelas de outros animais durante o transporte, e marcas de pancadas a que foram sujeitos durante $o$ encaminhamento)

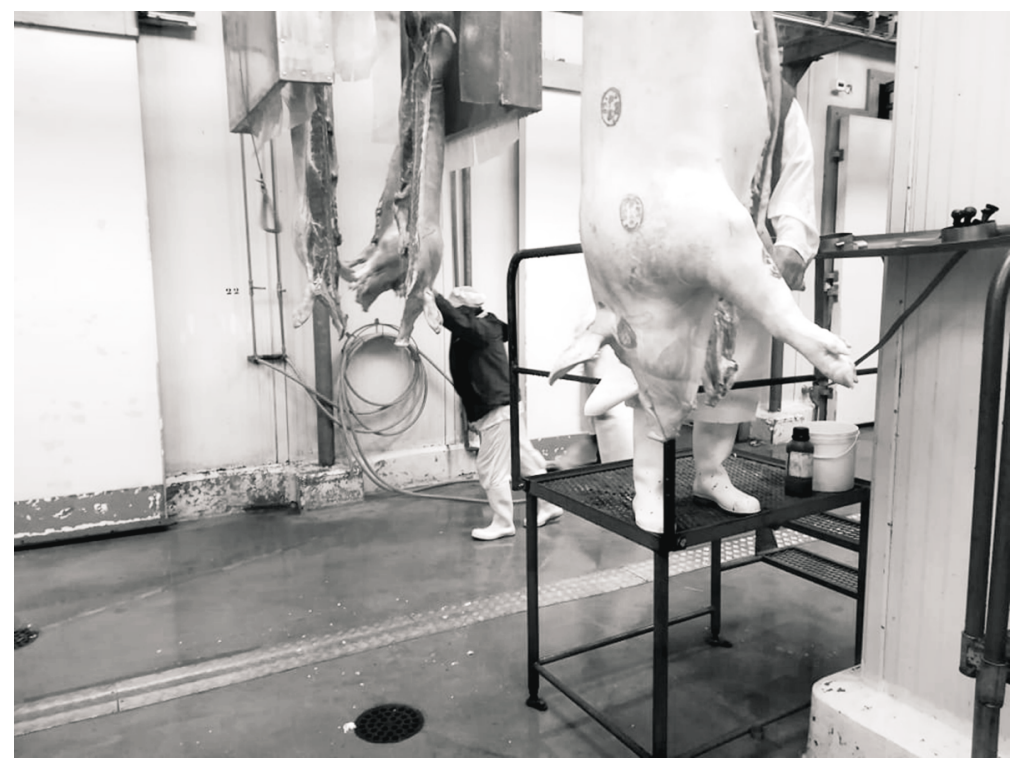

Figura 18 Fim da linha de abate (pesagem e colocação da marca de salubridade) 


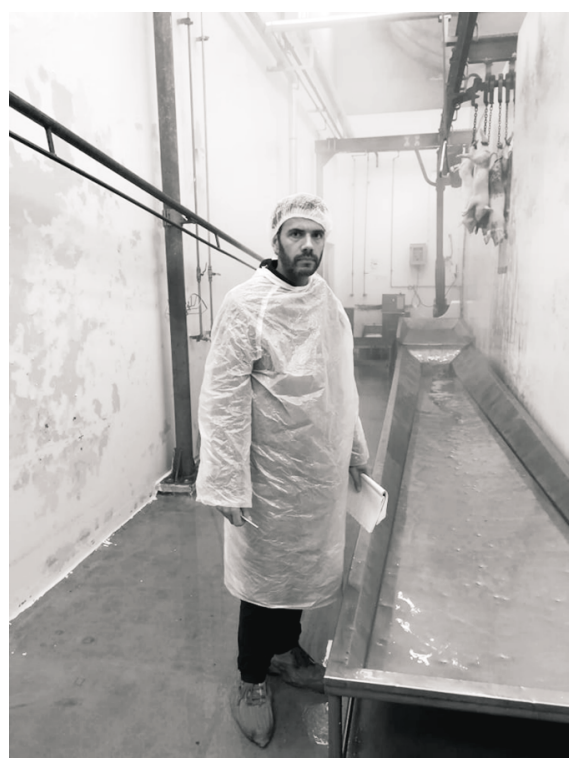

Figura 19 O investigador, no término do trabalho de observação

\section{Referências bibliográficas}

Adams, Carol J. (2003), The Pornography of Meat, Nova Iorque, Continuum.

Almeida, Miguel Vale de (1995), Senhores de Si. Uma Interpretação Antropológica da Masculinidade, Lisboa, Fim de Século.

Associação Portuguesa de Criadores da Raça Bovina (2008), Notícias Limousine, 17. Bourdieu, Pierre (1998), La Dominación Masculina, Barcelona, Editorial Anagrama .

Diretiva n. 9 93/119/CE, do Conselho, de 22 de Dezembro, relativa à "Proteção dos animais no abate e/ou occisão", disponível em:

https://dre.pt/pesquisa/-/search/548449/details/maximized?dreId=106397 (última consulta em setembro de 2019).

Engdahl, William F. (2005), Bird Flu and Chicken Factory Farms, Profit Bonanza for US Agribusiness, Global Research, disponível em: http://www.globalresearch.ca/index.php?context=va\&aid=1333 (última consulta em setembro de 2019).

Fonseca, Rui Pedro (2019), "As atitudes de indivíduos para com os animais suínos em produção familiar e pequena produção", Revista Latinoamerica de Estudios Críticos Animales, VI (1), pp. 215-243.

INE - Instituto Nacional de Estatística (2016) “Inquérito à estrutura das explorações agrícolas - dirigentes da exploração agrícola por orientação técnico-económica e sexo".

INE - Instituto Nacional de Estatística (2018), “Consumo humano de carne per capita (kg/ hab,)", disponível em: 
https://www.ine.pt/xportal/xmain?xpid=INE\&xpgid=ine_indicadores\&indOcorrCod= 0000211\&contexto=bd\&selTab=tab2\&xlang=pt (última consulta em setembro de 2019).

Kheel, Marti (1996), "The killing game: na ecofeminist critique of hunting”, Journal of the Philosophy of Sport, 23 (1), pp. 30-44, disponível em: https://www.tandfonline.com/doi/abs/10.1080/00948705.1996.9714529 (última consulta em setembro de 2019).

Méchin, Colette (1991), "Les règles de la bonne mort animale en Europe occidentale", L'Homme, 31 (120), pp. 51-67, disponível em: https://www.persee.fr/doc/hom_0439-4216_1991_num_31_120_369444 (última consulta em setembro de 2019).

Meliciano, Mara Alexandra (2011), Bem-Estar Animal em Alguns Suínos e Efeitos em Alguns Parâmetros da Segurança e Qualidade da Carne, Santarém, Instituto Politécnico de Santarém, dissertação para a obtenção do grau de mestre na área de Sistemas de Prevenção e Controlo Alimentar.

Pachirat, Timothy (2011), Every Twelve Seconds (Industrialized Slaughter and the Politics of Sight), Yale, Yale University Press.

Parry, Jovian (2010), “Gender and slaughter in popular gastronomy”, Feminism $\mathcal{E}$ Psychology, 20 (3), pp. 281-386, disponível em: https://journals,sagepub.com/doi/abs/10,1177/0959353510368129 (última consulta em setembro de 2019).

Pereira, Inês (2003), “Construção identitária em rede”, em Graça Índias Cordeiro, Luís Vicente Baptista e António Firmino da Costa (orgs.), Etnografias Urbanas, Oeiras, Celta Editora.

Rogers, Richard A. (2008), “Beasts, burgers, and hummers: meat and the crisis of masculinity in contemporary television advertisements", Enviornmental Communication, 2 (3), pp. 281-301.

UN-FAO - United Nations - Food and Agriculture Organization (2009/2010), Efetivos Animais, disponível em: http://www.fao.org/fileadmin/templates/ess/ess_test_folder/World_Census_Agricu lture/Country_info_2010/Reports/Reports_2/PRT_POR_REP,VOL2_2009,pdf (última consulta em setembro de 2019).

Wilkie, Rhoda M. (2010) Livestock/Deadstock (Working with Farm Animals from Birth to Slaughter), Filadélfia, Temple University Press.

Rui Pedro Fonseca, Investigador no Instituto Universitário de Lisboa (ISCTE-IUL), Centro de Investigação e Estudos de Sociologia (CIES-IUL), Lisboa, Portugal, E-mail: fonsecarppd@hotmail.com / rppfa1@iscte-iul.pt

Receção: 25 de junho de 2019 Aprovação: 13 de setembro de 2019 